(C) Group of authors, 2021

UDC 657.6:616-009.614.089-054.2

DOI - https://doi.org/10.14300/mnnc.2021.16036

ISSN - 2073-8137

\title{
INTERNAL ANESTHETIC AUDIT USING THE REGISTRATION OF CRITICAL INCIDENTS DURING ANESTHETIC PROCEDURES FOR «ONE-DAY SURGERY» IN CHILDREN
}

\author{
Nasibova E. M. 1, Poluxov R. Sh. 1, \\ Poluxova A. A. ${ }^{1}$, Obedin A. N. ${ }^{2}$, Obedina S. A. ${ }^{2}$ \\ ${ }^{1}$ Azerbaijan Medical University, Baku, Azerbaijan \\ 2 Stavropol State Medical University, Russian Federation

\section{ВНУТРЕННИЙ АНЕСТЕЗИОАОГИЧЕСКИЙ АУАИТ, ОСНОВАННЫЙ НА РЕГИСТРАЦИИ КРИТИЧЕСКИХ ИНЦИАЕНТОВ ВО ВРЕМЯ АНЕСТЕЗИОАОГИЧЕСКИХ ПРОЦЕАУР «ХИРУРГИИ ОАНОГО АНЯ» У АЕТЕЙ}

Э. М. Насибова ', Р. Ш. Полухов ',
А. А. Полухова ${ }^{1}$ А. Н. Обелин ${ }^{2}$, С. А. Обелина ${ }^{2}$
1 АзербайАжанский меАицинский университет, Баку, АзербайАжан
2 Ставропольский госУАарственный МеАицинский Университет, Российская ФеАерация

This article discusses the audit of undesirable events in outpatient anesthesiology during "one-day surgery» in pediatric surgical practice. We performed a qualitative assessment of the most common critical conditions and the time of their occurrence, depending on the stage of general anesthesia, in children. We also established the safest anesthesia methods in pediatric practice during «one-day surgery».

Keywords: outpatient surgery, complications of anesthesia, children, pediatric surgery, audit of adverse events, anesthesiology

Рассматривается вопрос аудита нежелательных событий в амбулаторной анестезиологии при проведении хирургических вмешательств «одного дня» в детской хирургической практике. Дается качественная оценка наиболее часто встречающимся критическим состояниям и времени их возникновения в зависимости от стадии проведения общей анестезии у детей. Кроме того, в исследовании устанавливаются наиболее безопасные методы анестезиологического пособия в детской практике при проведении операций «хирургии одного дня».

Ключевые слова: амбулаторная хирургия, осложнения анестезии, дети, детская хирургия, аудит нежелательных событий, анестезиология

For citation: Nasibova E. M., Poluxov R. Sh., Poluxova A. A., Obedin A. N., Obedina S. A. INTERNAL ANESTHETIC AUDIT USING THE REGISTRATION OF CRITICAL INCIDENTS DURING ANESTHETIC PROCEDURES FOR «ONE-DAY SURGERY»IN CHILDREN. Medical News of North Caucasus. 2021;16(2):162-165.

DOI - https://doi.org/10.14300/mnnc.2021.16036

Для цитирования: Насибова Э. М., Полухов Р. Ш., Полухова А. А., Обедин А. Н., Обедина С. А. ВНУТРЕННИЙ АНЕСТЕЗИОЛОГИЧЕСКИЙ АУДИТ, ОСНОВАННЫЙ НА РЕГИСТРАЦИИ КРИТИЧЕСКИХ ИНЦИДЕНТОВ ВО ВРЕМЯ АНЕСТЕЗИОЛОГИЧЕСКИХ ПРОЦЕДУР «ХИРУРГИИ ОДНОГО ДНЯ» У ДЕТЕЙ. МеДИцИнскИЙ вестник Северного Кавказа. 2021;16(2):162-165. DOI - https://doi.org/10.14300/mnnc.2021.16036

\footnotetext{
AIDS- autoimmune deficiency syndrome

CI - critical incident

CIRI - critical incident rate index

FCR - frequency of critical incidents
}

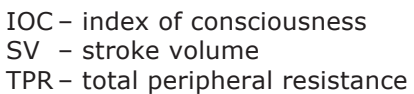

P atient safety is not a simple issue that interests only anesthesiologists; preventing adverse injuries during treatment or minimizing damage if they occur is one of the most pressing problems in medicine (National Patient Safety Foundation, 1999). Thus, for many countries over the past decade, patient safety during treatment has become a national problem. In 1997, at least 44,000 patients in the USA died because of medical errors (American Hospital Association, 1999, EJ Thomas, et al., $1999 ; 2000)$. Mortality due to medical errors is currently ranked 8th highest among other causes of death, ahead of road traffic accidents, breast cancer, and autoimmune deficiency syndrome (AIDS) 
(Centers for Disease Control and Prevention, 1999). Although anesthesiology is currently characterized by low mortality, the causes of death and severe complications during anesthesia have remained the same for the last $\mathbf{2 0}$ years. In anesthesiology practice, with insufficiently experienced operating room personnel, conditions may become potentially life-threatening for the patient in much larger numbers than in other specialties. Operating room personnel require significant theoretical training in various fields of medicine, tremendous skills and abilities, as well as the utmost concentration and attention when performing anesthesia. During surgical interventions, the results obviously depend on the surgeon's skill, but also on the anesthesiologist's skill in providing support, correction, and, if necessary, restoration of vital functions and, consequently, the patient's life. Therefore, worldwide, patient safety is associated primarily with anesthesiology [1-3]. Numerous studies have shown that one of the ways to improve patient safety in anesthesiology is to simplify and standardize processes, and for a particular clinic, one of the significant sections of this work is the internal medical audit. An internal medical audit («audit»: an independent review) is a relatively new method of evaluating a department's work that allows institutions, by analyzing the collected data, to identify weaknesses that require improvement. The internal audit is used to develop and modify various protocols and instructions governing clinical activity [4-7]. Until recently, in anesthesiology, a medical audit meant an analysis of the department's activities, the main criterion of which was to determine anesthesia-related mortality or, at best, the incidence of serious complications [8-11]. Currently, an internal anesthetic audit is understood a systematic evaluation (involving an analysis of specific clinical observations) of the quality of the anesthetic procedures and their compliance with the established protocols, as well as an assessment of the effectiveness of the implemented protocols and their suitability for achieving the set goals [12, 13].

Aim of the study: was development of a system to perform internal anesthetic audits for "one-day surgery» in children. Achieving this goal involved the following tasks: Protocols for intravenous total anesthesia during one-day surgery in children were developed. A list of undesirable events was determined, and a protocol for registering critical incidents was created. An internal anesthetic audit was then performed. The dependence of the frequency of critical incidents on various types of anesthesia was identified; the safest methods of pain relief in one-day surgery in children was determined; and the effectiveness of introducing new anesthesia protocols for children in the one-day surgery department was evaluated.

Material and Methods. This study was performed at the Department of Pediatric Surgery of Azerbaijan Medical University as well as the Regional Children's Clinical Hospital, Stavropol from 2015 to 2020. The inclusion criteria were: patients aged $0-15$ years; risk of class I-II anesthesia according to the American Society of Anesthesiologists (ASA) classification; average operation duration $\leq 45$ minutes; and no contraindications for regional (caudal) anesthesia. The exclusion criteria were: refusal to participate in the study or change in the anesthetic plan intraoperatively (e.g., changing to inhalational anesthesia) or requiring muscle relaxants intraoperatively.

A total of 520 children who met the inclusion criteria took part in the study. All children underwent various short- term minimally invasive surgical interventions for: phimosis, cryptorchidism, varicocele, or small tumors of the bones and soft tissues of the lower extremities. After standard preoperative examination by an anesthesiologist, the patientswere randomly distributed using the random number method into groups according to the type of anesthesia. Using the exclusion criteria, 147 patients were removed from the study; thus, the final analysis was performed in 373 children. There were three observation groups according to the type of anesthesia: group I: propofol + fentanyl, $n=58$; group II: ketamine + midazolam + fentanyl, $\mathrm{n}=37$; and group III: propofol + caudal anesthesia, $n=278$. The groups were matched for age and sex. Hemodynamic parameters were monitored using Cardiocap monitors (Bionet BM7, Seoul, Republic of Korea), and central hemodynamic indices (stroke volume (SV), index of consciousness (IOC), total peripheral resistance (TPR)) were calculated according to generally accepted formulas while considering the age interval. Ventilation parameters and oxygen concentration in the circuit were recorded using a Dräger respiratory monitor. A critical incident $(\mathrm{Cl})$ was considered an undesirable event during and after anesthesia, which, in the absence of intervention, could lead to undesirable consequences (Gaba H., 1992). The presence of $\mathrm{Cl}$ was determined intraand postoperatively. The list of such events was compiled by the authors in accordance with the lists of Cls in studies by T. S. Vitez (1990), T. Giraud (1993), S. Fasting (1996), A. Troyen (1991), and Gaba (1994) and were refined locally after analyzing the current clinical practice. The list of Cls included the following conditions: 1) malfunctions in oxygen and respiratory equipment, 2) problems with monitors, 3) dosing device malfunctions, 4) moderate hypoxemia (blood oxygen saturation (SpO2): $90 \%-95 \%$ ), 5) critical hypoxemia (SpO2<90 \%), 6) regurgitation, 7) aspiration, 8) bronchospasm, 9) cardiac arrest, 10) bradycardia (heart rate $<60$ beats per minute), 11) increased blood pressure $20 \%$ higher than usual, 12) decreased blood pressure, 13) accidental removal of a catheter from a peripheral vein, 14) brain death, 15) postoperative agitation, 16) hypothermia (body temperature $<36^{\circ} \mathrm{C}$ ), 17) nausea and a single episode of vomiting, 18) repeated vomiting, 19) chills and muscle tremors, 20) delayed recovery of consciousness postoperatively, 21) drug allergy, 22) excessively deep anesthesia, and 23) unreasonably superficial level of anesthesia. To control the quality of the anesthesia, the following integral indicators were also calculated: frequency of critical incidents (FCR), which is the ratio of the sum of registered critical incidents to the number of observations in the group, and the critical incident rate index (CIRI), which is the number of critical incidents per hour of anesthesia.

The results were analyzed using standard variable statistics and Student's t-test (Microsoft Excel software package). For all statistical analyses, significance was set at $5 \%$ or $1 \%$; i.e., the results were considered statistically significant at $p<0.05$ or $p<0.01$.

Results and Discussion. The internal medical audit revealed 498 cases of $\mathrm{Cl}$ in various types of general anesthesia for «minor» surgical interventions in children (Table 1). An analysis of the number of critical incidents at various stages of general anesthesia showed that such events occurred most often during anesthetic induction and postoperatively (Table 2). The need for respiratory support in the form of mechanical ventilation and assisted ventilation arose mainly in patients in group I $(36.8 \%)$. In the majority of the patients in group II (93.4\%), there were no disorders of spontaneous breathing throughout the anesthesia. Moderate hypoxemia was observed in group I in 4 patients (6.9\%). In group III, only 5 patients $(1.8 \%)$ developed moderate hypoxemia, which resolved spontaneously and did not require correction. Critical hypoxemia $(\mathrm{SpO} 2<90 \%)$ requiring auxiliary ventilation 
was noted in group I in 4 patients $(6.9 \%)$. This was explained by an increase in chest rigidity and lung hypoventilation owing to an increase in the fentanyl dose to provide adequate pain relief. Two patients in this group were intubated owing to severe hypoxemia. None of the patients in group III developed critical hypoxemia. Persistent pressure fluctuations according to two blood pressure measurements at 5-minute intervals were recorded in 7 patients $(n=58,12.1 \%)$ in group I and in 28 patients ( $n=37,75.0 \%)$ in group II. Prolonged awakening or prolonged sleep was observed in $8(n=58,613.8 \%)$ patients in group I and in $5(n=37,13.5 \%)$ patients in group II. The largest number of critical incidents was associated with respiratory problems (39.1\%), and the anesthetic depth was insufficient in $8.3 \%$ of the cases. Of the critical incidents associated with the cardiovascular system (16.6\%), tachycardia and arterial hypertension were noted most often. The smallest number of critical incidents was associated with equipment malfunctions $(0.7 \%)$, and the total number of critical incidents was 498 ( 0.63 per one general anesthesia).

Numbers of critical events during anesthesia

\begin{tabular}{|c|c|c|c|c|c|}
\hline $\begin{array}{l}\text { Critical } \\
\text { event }\end{array}$ & $\begin{array}{l}\text { Indu- } \\
\text { cing } \\
\text { anes- } \\
\text { thesia }\end{array}$ & $\begin{array}{l}\text { Main- } \\
\text { taining } \\
\text { anes- } \\
\text { thesia }\end{array}$ & $\begin{array}{l}\text { Awa- } \\
\text { kening }\end{array}$ & $\begin{array}{l}\text { Post- } \\
\text { opera- } \\
\text { tive } \\
\text { period }\end{array}$ & Total \\
\hline Bronchospasm & 1 & - & 1 & - & 2 \\
\hline Laryngospasm & 18 & 3 & 4 & - & 25 \\
\hline $\begin{array}{l}\text { Hypoventilation } \\
(\mathrm{RR}<10)\end{array}$ & 12 & 5 & 3 & - & 20 \\
\hline Cough & 14 & 5 & - & - & 19 \\
\hline $\begin{array}{l}\text { Critical } \\
\text { hypoxemia }\end{array}$ & 7 & 5 & - & - & 12 \\
\hline Allergy & 8 & - & - & - & 8 \\
\hline $\begin{array}{l}\text { Difficult } \\
\text { intubation }\end{array}$ & 3 & - & - & - & 3 \\
\hline $\begin{array}{l}\text { Moderate } \\
\text { hypoxemia }\end{array}$ & 18 & 6 & 7 & 2 & 33 \\
\hline Bradycardia & 15 & 5 & - & - & 20 \\
\hline Tachycardia & 6 & 10 & 1 & 3 & 20 \\
\hline Arrhythmia & 5 & - & 3 & - & 8 \\
\hline $\begin{array}{l}\text { Arterial } \\
\text { hypotension }\end{array}$ & 31 & 23 & 5 & - & 59 \\
\hline Nausea & - & - & 20 & 25 & 45 \\
\hline $\begin{array}{l}\text { Motor } \\
\text { excitement }\end{array}$ & 26 & 2 & 7 & - & 35 \\
\hline $\begin{array}{l}\text { Prolonged } \\
\text { sleep }\end{array}$ & - & - & - & 25 & 25 \\
\hline Vomiting & - & - & 3 & 21 & 24 \\
\hline Hallucinations & - & - & 10 & 5 & 15 \\
\hline $\begin{array}{l}\text { Chills and } \\
\text { muscle tremors }\end{array}$ & - & - & 27 & 2 & 29 \\
\hline $\begin{array}{l}\text { Skeletal muscle } \\
\text { hypertonicity }\end{array}$ & 20 & - & 3 & - & 23 \\
\hline $\begin{array}{l}\text { Delayed motor } \\
\text { activity }\end{array}$ & & & - & 31 & 31 \\
\hline $\begin{array}{l}\text { Delayed } \\
\text { urination }\end{array}$ & - & - & - & 11 & 11 \\
\hline Diplopia & - & - & 9 & 7 & 16 \\
\hline Dizziness & - & - & 6 & 3 & 9 \\
\hline Headache & - & - & - & 3 & 3 \\
\hline Hiccups & - & - & 2 & 1 & 3 \\
\hline Total & 184 & 64 & 111 & 139 & 498 \\
\hline $\begin{array}{l}\text { Rate per } \\
\text { patient }\end{array}$ & $\begin{array}{c}0.23 \pm \\
0.02\end{array}$ & $\begin{array}{c}0.08 \pm \\
0.01\end{array}$ & $\begin{array}{c}0.14 \pm \\
0.01\end{array}$ & $\begin{array}{c}0.18 \pm \\
0.01\end{array}$ & $\begin{array}{c}0.63 \pm \\
0.03\end{array}$ \\
\hline
\end{tabular}

Note. Data indicate the numbers of critical incidents related to each event.
Number of critical events (per 1 patient), $\mathbf{M} \pm \mathbf{m}$

\begin{tabular}{|l|c|c|c|}
\hline $\begin{array}{l}\text { Period of the } \\
\text { critical event }\end{array}$ & $\begin{array}{c}\text { Group I } \\
\mathrm{n}=58\end{array}$ & $\begin{array}{c}\text { Group II } \\
\mathrm{n}=37\end{array}$ & $\begin{array}{c}\text { Group III } \\
\mathrm{n}=278\end{array}$ \\
\hline $\begin{array}{l}\text { During } \\
\text { anesthesia }\end{array}$ & $\begin{array}{c}37 \\
0.64 \pm 0.10\end{array}$ & $\begin{array}{c}68 \\
1.84 \pm 0.22\end{array}$ & $\begin{array}{c}32 \\
0.12 \pm 0.02\end{array}$ \\
\hline $\begin{array}{l}\text { Postoperative } \\
\text { period }\end{array}$ & 18 & 65 & 67 \\
\hline Total & $0.31 \pm 0.07$ & $1.76 \pm 0.22$ & $0.24 \pm 0.03$ \\
\hline & $\begin{array}{c}55 \\
0.95 \pm 0.13\end{array}$ & $3.59 \pm 0.31$ & $0.36 \pm 0.04$ \\
\hline
\end{tabular}

Of the total number of critical incidents associated with the central and peripheral nervous systems $(n=126)$, the largest percentage $(46.8 \%)$ was observed in group $\mathrm{I}$, and the smallest percentage $(7.9 \%)$ was observed in group III.

Similar data have been obtained in previous studies. The working group of the European Society of Anesthesiologists in the APRICOT clinical trial (2017) noted that from 1 April 2014 to 31 January 2015, among 31127 anesthetic procedures in 30874 children with an average age of $6-15$ years, the perioperative incidence of severe critical events was $5.2 \%$ (95\% confidence interval: $5.0-5.5)$, with an incidence of respiratory critical events of $3.1 \%$ (95 \% confidence interval: 2.9-3.3) [14-17]. Cardiovascular instability occurred in $1.9 \%$ (95\% confidence interval: 1.7-2.1), with an immediate unfavorable outcome in $5.4 \%$ (95\% confidence interval: 3.7-7.5) of these cases. However, no dependence on the type of anesthesia was found. Age (relative risk: 0.88, $95 \%$ confidence interval: $0.86-0.90 ; p<0.00001)$, and medical history and physical condition (relative risk: 1.60, $95 \%$ confidence interval: $1.40-1.82 ; p<0.00001$ ) were the main factors associated with the risk of a serious critical event [18-20].

A study from Pakistan (Sobia Khan et al., 2018) described incidents related to pediatric practice. Cls in children from the neonatal period to 12 years of age were studied. All Cl records collected between January 1998 and December 2012 at the Anesthesiology Department of the Aga Khan University Hospital were reviewed. The study was a retrospective review of the critical incident form, which was used to record all critical incidents. Since 1998, the department has used a structured form to record critical incidents, which is periodically assessed and, if necessary, creatively reworked. A total of 451 pediatric critical incidents were recorded in the study; $34 \%$ were reported in infants, $96 \%$ occurred during routine operations, and only $4 \%$ occurred during emergency operations. Equipmentrelated events $(n=114)$, respiratory events $(n=112)$, and drug-related events $(n=110)$ were equally distributed (25.6\%, $25.3 \%$, and $24.7 \%$, respectively). Human factors accounted for $74 \%$ of reports, followed by equipment failures (10\%) and patient factors ( $8 \%$ ). Only $5 \%$ of the incidents were the result of system errors. Failure to check (equipment/drugs/doses) was the most common cause of human error, and poor outcomes were observed in $7 \%$ of the cases. In conclusion, the authors recommended quality improvement projects in anesthesiology, as well as training residents and staff to deal with airway problems in pediatric patients $[21,22]$.

Conclusions. Internal anesthetic audits, based on the registration of critical incidents, eliminates the least safe method of intravenous total anesthesia in one-day surgery in children. According to our data, the least safe total intravenous anesthesia in one-day surgery in children was anesthesia with a combination of propofol, fentanyl, and ketamine. An internal anesthetic audit using the registration of critical incidents makes it possible to draw conclusions 
about the influence of certain factors on the incidence of intra- and postoperative complications. Internal anesthetic audits can be used to predict and prevent complications and, ultimately, significantly increase patient safety by providing adequate anesthetic support during one-day surgery in children.

Disclosures: The authors declare no conflict of interest.

Acknowledgment. We thank Jane Charbonneau, DVM, from Edanz (www.edanz.com/ac) for editing a draft of this manuscript.

References

1. Habre W., Disma N., Virag K., Becke K., Hansen T. G. [et al.] APRICOT Group of the European Society of Anaesthesiology Clinical Trial Network. Incidence of severe critical events in paediatric anaesthesia (APRICOT): a prospective multicentre observational study in 261 hospitals in Europe. Lancet Respir Med. 2017:5(5): 412-425. https://doi.org/10.1016/S2213-2600(17)30116-9

2. Rudd K. E., Johnson S. C., Agesa K. M., Shackelford K. A., Tsoi D. [et al.] Global, regional, and national sepsis incidence and mortality, 1990-2017: analysis for the Global Burden of Disease Study. Lancet. 2020;395(10219):200211. https://doi.org/10.1016/S0140-6736(19)32989-7

3. Abbasi S., Khan F. A., Khan S. Pediatric critical incidents reported over 15 years at a tertiary care teaching hospital of a developing country. J. Anaesthesiol. Clin. Pharmacol. 2018;34(1):78-83.

https://doi.org/10.4103/joacp.JOACP 24016

4. Engelhardt T., Fiadjoe J.E., Weiss M., Bāker P., Bew S. [et al.] A framework for the management of the pediatric airway. Paediatr. Anaesth. 2019;29(10):985-992. https://doi.org/10.1111/pan.13716

5. Lee J. H., Kim E. K., Song I. K., Kim E. H., Kim H. S. [et al.] Critical incidents, including cardiac arrest, associated with pediatric anesthesia at a tertiary teaching children's hospital. Paediatr. Anaesth. 2016;26(4):409-17. https://doi.org/10.1111/pan.12862

6. Kupersztych-Hagege E., Duracher-Gout C., Ortego R. Carli P., Orliaguet G. Critical incidents in a French department of paediatric anaesthesia. Anaesth. Crit. Care Pain Med. 2017;36(2):103-107. https://doi.org/10.1016/j.accpm.2016.04.004

7. Holmberg M. J., Ross C. E., Fitzmaurice G. M., Chan P. S., Duval-Arnould J. [et al.] American Heart Association's Get With The Guidelines-Resuscitation Investigators. Annual Incidence of Adult and Pediatric In-Hospital Cardiac Arrest in the United States. Circ. Cardiovasc. Qual. Outcomes. 2019;12(7):e005580.

8. MacLennan A. I., Smith A. F. An analysis of critical incidents relevant to pediatric anesthesia reported to the UK National Reporting and Learning System, 2006-2008. Paediatr. Anaesth. 2011:21(8):841-7. https://doi.org/10.1111/j.1460-9592.2010.03421.x

9. Singh Bajwa S. J., Bajwa S. K., Kaur J. Comparison of two drug combinations in total intravenous anesthesia: Propofol-ketamine and propofol-fentanyl. Saudi J. Anaesth. 2010:4:72-79

10. Verma R., Alladi R., Jackson I., Johnston I., Kumar., Page R. [et al.] Guide lines - Day case and short stay surgery: 2. Anaesthesia. 2011;66:417-423.
11. Association of Anaesthetists of Great Britain and Ireland; British Association of Day Surgery. Day case and short stay surgery: 2. Anaesthesia. 2011;66:417-434.

12. Kuklin V. N. Anaesthesia for day case surgery. Review. Annals of Critical Care. 2020;4:88-98. https://doi.org/10.21320/1818-474X-2020-4-88-98

13. American Society of Anesthesiologists. Office Based Anesthesia: Considerations for Anesthesiologists in Setting Up and Maintaining a Safe Office Anesthesia Environment, from ASA Committee on Ambulatory Society for Ambulatory Anesthesia (SAMBA) Committee on Office Based Anesthesia; 2008. Available at: http://www.asahq.org/ publicationsAndServices/ofce.pdf. [Last accessed on 2020 Nov 16].

14. Clarke S. Pediatric inguinal hernia and hydrocele: an evidence-based review in the era of minimal access surgery. J. Laparoendosc. Adv. Surg. Tech. A. 2010;20(3):305-309.

15. Segerdahl M., Warrén-Stomberg M., Rawal N., Brattwall M., Jakobsson J. Children in day surgery: clinical practice and routines. The results from a nation-wide survey. Acta Anaesthesiol. Scand. 2008;52:821-828. https://doi.org/10.1111/j.1399-6576.2008.01669.x

16. Bailey C. K., Ahuja M., Bartholomew K., Bew S., Forbes L. [et al.] Guidelines for day-case surgery 2019. Guidelines from the Association of Anaesthetists and the British Association of Day Surgery. Anaesthesia. 2019;74:778-792. https://doi.org/10.1111/anae.14639

17. Visioni A., Shah R., Gabriel E., Attwood K., Kukar M., Nurkin S. Enhanced Recovery After Surgery for Noncolorectal Surgery? A Systematic Review and Meta-analysis of Major Abdominal Surgery. Ann Surg. 2018;267(1):57-65 https://doi.org/10.1097/SLA.0000000000002267

18. Strauss J. M, Giest J. Total intravenous anesthesia. On the way to standard practice in pediatrics. Anaesthesist. 2003;52:763-77.

19. Rasmussen L. S., Steinmetz J. Ambulatory anaesthesia and cognitive dysfunction. Curr. Opin. Anaesthesiol. 2015;28:631-635

https://doi.org/10.1097/ACO.0000000000000247

20. Lonnqvist P. A, Morton N. S. Paediatric day-case anaesthesia and pain control. Curr. Opin. Anaesthesiol. 2006;19:617-621.

21. Obedin A. N., Alexandrov A. E., Kirgizov I V. [et al.] Intensive care of newborns with congenital abnormalities of gasrtointestinal tract and high risk of septic complications. Pediatric Surgery. 2013;(1):19-24.

22. Feltman D. M., Weiss M. G., Nicoski P. Sinacore J. Rocuronium for nonemergent intubation of term and preterm infants. Journal of Perinatology. 2011;31(1):38-43.

\section{About authors:}

Nasibova Esmira Mirza, MD, Associate Professor, Department of pediatric surgery tel.: +994773366077; e-mail: Nasibova_esmira@mail.ru

Poluxov Ramiz Shamil, MD, DMSc, Professor, Head of Department of pediatric surgery; tel.: +994503162699; e-mail: Poluxov@mail.ru

Poluxova Aynur Ali, PhD, Associate Professor of the Department of the $2^{\text {nd }}$ pediatrics; tel.: +994503501896; e-mail: aynurpoluxova@mail.ru

Obedin Alexander Nickolaevich, MD, PhD, Chief of Department of anesthesiology, intensive care and emergency medicine; tel.: +79034169771; e-mail: volander@mail.ru

Obedina Svetlana Alexandrovna, Assistant of the Department of biology:

tel.: +79283118587; e-mail: o.s.a.228@gmail.com 